\title{
Waste management as an element of sustainable development of the circular economy in the European Union
}

\author{
Dilbar Sultanova ${ }^{1}$, Anna Maliashova ${ }^{1, *}$, and Svetlana Gadelshina ${ }^{1}$ \\ ${ }^{1}$ Kazan National Research Technological University, Russian Federation
}

\begin{abstract}
The problems of waste disposal at the present stage of development all over the world are the most important. Waste accumulation is an acute problem in all countries. Waste damages the soil, affects the quality of life of the population and damages the vital functions of all living organisms. The decomposition time of some types of garbage is more than 500 years. Rapid population growth increases waste. The problem of their utilization is a promising area of development for all countries. In the countries of the European Union a waste management system has been developed, which gives positive results. The article discusses the main aspects of waste management policy in the countries of the European Union. The data of the general European trend in the formation of household waste for the last two decades are presented. Hypotheses about what factors can influence the correctness of the waste management policy were tested using regression analysis. The recycling rate of waste, the circular material use rate, as well as trade in secondary raw materials were chosen as indicators of the level of development of waste management. The level of GDP, R\&D costs, human resources in science and technology were selected as factors of the effectiveness of this policy. Indicators have been identified that have the greatest impact on the degree of waste disposal.
\end{abstract}

\section{Introduction}

The emergence of waste disposal problems is associated with technical progress, as a result of which new materials have appeared that require special disposal methods.

Over the past decades, the countries of the European Union have shifted the vector of waste management towards waste prevention and recycling. This waste management policy is important for extracting more value from resources while reducing the burden on the environment. Household waste accounts for only $14 \%$ of the total, but despite this, this value is noticeable for the population and the state [1]. Safe handling of this waste will reduce the negative impact on the environment [2 5].

An increase in waste generation is observed throughout the world [4, $6-8]$. This trend will continue in the future. According to forecasts, the annual amount of garbage from 2016 to 2050 will increase by $70 \%$ to reach 3.40 billion tons $[9,10]$.

There are five main streams in the total volume of waste:

- Industrial waste (26\%);

- Waste from the mining industry (29\%);

- Construction waste (22\%);

- Solid household waste (14\%) [1].

To date, the European Union has developed the concept of a waste management sequence - "Waste management hierarchy" (Fig. 1) [11, 12]. The waste management hierarchy is developed in accordance with Directive 2008/98 / EC.

According to Directive 2008/98 / EC, waste prevention comes first $[11,12]$. According to Directive 2008/98 / EC, "prevention" is "measures that are taken before a substance, material or product becomes waste, and which reduce in advance:

a) the amount of waste, including the reuse of products or an increase in their life cycle;

b) the negative impact of the generated waste on the environment and human health;

c) the content of hazardous substances in materials and products. "

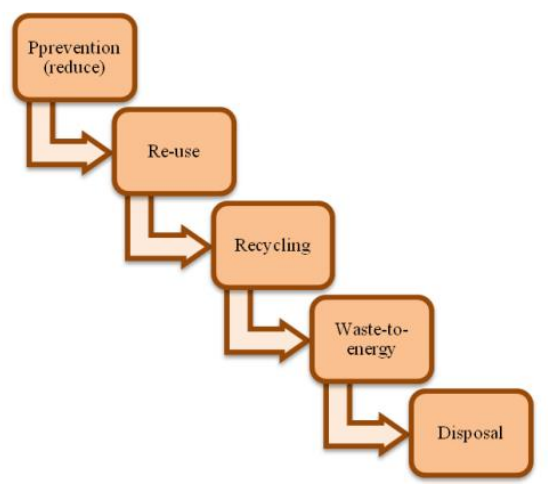

Fig. 1. Waste management hierarchy in the European Union.

The next step is recycling [11-14]. Recycling is any operation in which a waste material is processed into

* Corresponding author: annamalyashova@gmail.com 
products, materials or substances, regardless of whether the resulting product serves its original purpose or for some other purpose. Recycling is a key element of the waste management system in the European Union. According to the Directive, the countries of the European Union must take the necessary measures to achieve the following objectives [12]:

a) preparation for reuse and recycling of waste such as at least paper, metal, plastic and glass from households and possibly from other sources, since these waste streams are similar to waste from households, should be increased to minimum $50 \%$ by weight;

b) preparation for reuse, recycling and recovery of other material, including backfilling operations using waste to replace other materials, non-hazardous construction waste and demolition waste, except for materials of natural origin defined in category 170504 in the waste list, should be increased to at least $70 \%$ by weight.

The next level of the waste management hierarchy is the use of waste for other purposes. First of all, it means waste recovery in order to obtain energy (waste-toenergy) [12, 15 - 19].

The next step in waste management is its disposal (landfill) [11]. The directive established that landfill disposal is only permissible for waste that has treatment.

With the development of the waste management system in the European Union, an economic instrument has emerged that makes it possible to regulate waste [11, 12]:

a) taxation of both landfill disposal of waste and their incineration;

b) variants of schemes "you pay as much as you throw away" (principle "polluter pays");

c) options for producer liability schemes for special types of waste.

In connection with the adopted legal instruments, the volumes of landfill of household waste in the countries of the European Union are decreasing, while waste processing is increasing (Fig. 2).

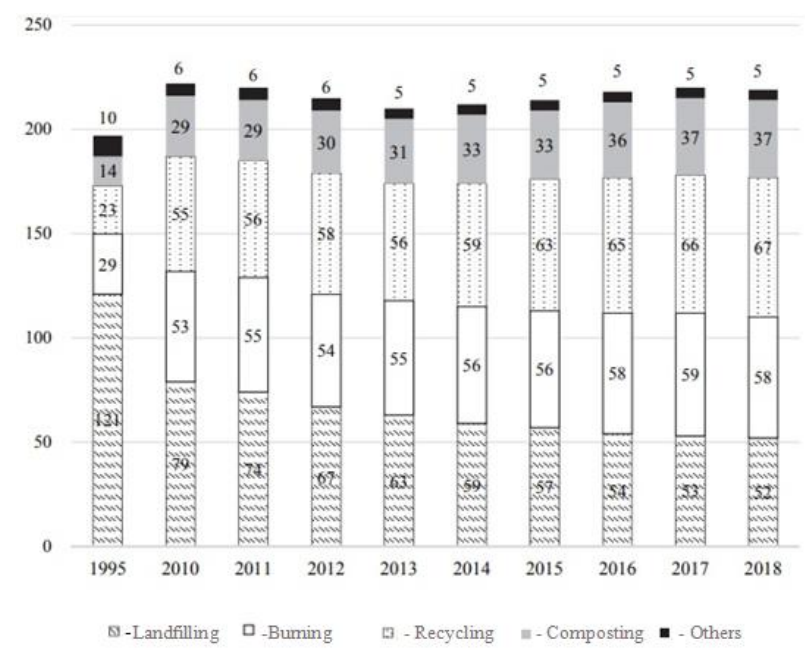

Fig. 2. Directions for the use of house hold waste in the European Union [20].

The level of waste disposal decreased from $61 \%$ in 1995 to $24 \%$ in 2018 . The volume of waste disposal at landfills decreased by $3.7 \%$ per year. These reductions can be partly explained by the application of European legislation.

In 2015, the European Commission adopted the program "Closing the loop - An EU action plan for the Circular Economy" [21]. The central idea of the program is "everything that is possible should be recyclable": "products, materials and resources should remain within the economy as long as possible and waste generation is minimized". In EU documents and expert commentary the circular economy of the future is presented as a revolution leading to a new technological order - to a sustainable, low-carbon, resource-efficient and competitive economy. In essence, the concept is a concretization of the philosophy of socio-economic development, which was outlined at the first UN Conference on Sustainable Development in Rio de Janeiro (1992): today it is one of the most important priorities of the entire "European project" [11].

The purpose of this article is to examine the path of sustainable development policies and circular economy in the leading countries of the movement and building awareness of a possible algorithm intensification of activities in countries where waste management issues are only at the initial stage.

\section{Materials and methods}

As the initial data for the study, we used the data of European statistics on the rate of waste disposal [22], as well as GDP indicators, R\&D costs, human resources in science and technology by country. The dynamics of waste generation in the countries of the European Union per capita is analyzed.

The analysis was carried out by the method of constructing a regression model. The main task of constructing a regression model is to identify the combination of factors that affect the simulated index. As simulated indicators of a successful waste management policy were chosen: the rate of waste utilization, the circular material use rate, and trade in secondary raw materials. The factors influencing the modelled indicators are the level of GDP, R\&D costs, human resources in science and technology. The result was examined using the Student's coefficient

\section{Results}

Analyzing the general European trend in the generation of household waste over the last two decades, one can trace the overall reduction in waste generation (Table 1). It should be noted that over the past nineteen years (2000-2019), the volumes of annually generated household waste in the countries of the European Union not only did not increase, despite the population growth, but even decreased slightly - from $513 \mathrm{~kg}$ / person to 502 $\mathrm{kg} /$ person [22].

From the above data, it can be seen that today the leading countries in waste generation are Denmark, Germany, Norway and Switzerland. More than fifty percent of the waste generated in these countries is 
recycled, including through composting and anaerobic disposal.

Table 1. Municipal waste recycling rate in the European Union per capita, $\mathrm{kg} /$ person [22].

\begin{tabular}{|l|c|c|c|c|c|c|}
\hline \multicolumn{1}{|c|}{ Country } & $\begin{array}{c}2000 \\
\text { year }\end{array}$ & $\begin{array}{c}2005 \\
\text { year }\end{array}$ & $\begin{array}{c}2010 \\
\text { year }\end{array}$ & $\begin{array}{c}2015 \\
\text { year }\end{array}$ & $\begin{array}{c}2018 \\
\text { year }\end{array}$ & $\begin{array}{c}2019 \\
\text { year }\end{array}$ \\
\hline EU-27 & 513 & 506 & 503 & 480 & 492 & 502 \\
\hline EU-28 & 512 & 515 & 504 & 481 & 488 & - \\
\hline Belgium & 471 & 482 & 456 & 412 & 409 & 415 \\
\hline Bulgaria & 612 & 588 & 554 & 419 & 407 & - \\
\hline Czech & 335 & 289 & 318 & 316 & 351 & - \\
\hline Denmark & 664 & 736 & - & 822 & 814 & 844 \\
\hline Germany & 642 & 565 & 602 & 632 & 606 & 609 \\
\hline Estonia & 453 & 433 & 305 & 359 & 405 & 394 \\
\hline Ireland & 599 & 731 & 624 & - & 598 & - \\
\hline Greece & 412 & 442 & 532 & 488 & 515 & - \\
\hline Spain & 653 & 588 & 510 & 456 & 475 & 476 \\
\hline France & 514 & 529 & 534 & 516 & 536 & 548 \\
\hline Croatia & 262 & 336 & 379 & 393 & 432 & 445 \\
\hline Italy & 509 & 546 & 547 & 486 & 499 & - \\
\hline Latvia & 271 & 320 & 324 & 404 & 407 & 439 \\
\hline Lithuania & 365 & 387 & 404 & 448 & 464 & 472 \\
\hline Hungary & 446 & 461 & 403 & 377 & 381 & 387 \\
\hline Netherlands & 598 & 623 & 571 & 523 & 511 & 508 \\
\hline Poland & 320 & 319 & 316 & 286 & 315 & 336 \\
\hline Portugal & 457 & 452 & 516 & 460 & 507 & 513 \\
\hline Romania & 355 & 383 & 313 & 247 & 272 & 280 \\
\hline Slovenia & 513 & 494 & 490 & 449 & 486 & 504 \\
\hline Slovakia & 254 & 273 & 319 & 329 & 414 & 421 \\
\hline Finland & 502 & 478 & 470 & 500 & 551 & 566 \\
\hline Sweden & 425 & 479 & 441 & 451 & 434 & 449 \\
\hline $\begin{array}{l}\text { Great } \\
\text { Britain }\end{array}$ & 577 & 581 & 509 & 483 & 463 & - \\
\hline Norway & 613 & 426 & 469 & 422 & 739 & 776 \\
\hline Switzerland & 659 & 664 & 711 & 728 & 706 & 709 \\
\hline
\end{tabular}

Analyzing the waste disposal policy, it was suggested that the criteria for the effectiveness of this policy could be the recycling rate of waste, the circular material use rate, as well as trade in secondary raw materials - paper, plastic, cardboard, precious metals, iron, steel, copper, aluminum, nickel. The following factors for the effectiveness of this policy were chosen: the level of GDP, expenditures on R\&D, human resources in science and technology.

Thus, three hypotheses need to be tested:

H1: the higher the level of GDP, the more attention is paid to waste disposal issues;

$\mathrm{H} 2$ : the higher the R\&D costs, the wider the range of technologies and new research in the field of recycling and return of recycled material to the circular economy;

$\mathrm{H} 3$ : the higher the share of human resources in science and technology, the higher the activity of the population in matters of waste disposal.

To test the modeled indicators were built three regression models, and the results were verified by the Student coefficient. Using this coefficient, the significance of a particular factor in the proposed models is determined.

The construction of regression models led us to the following results.

The garbage utilization rate model is as follows:

$$
Y_{2}(x)=2.93017 X_{2}
$$

where $X_{2}$ is $R \& D$ Cost, \% of GDP.

The rest of the factors introduced into the model did not significantly affect the result. The values of the coefficients were not comparable with the value of the Student's coefficient.

The construction of the second and third models, reflecting the degree of use of circular material and trade in secondary raw materials, none of the factors we identified were significant. It is likely that in the analysis of these models, other factors that we did not take into account at this stage of the study have a significant impact.

\section{Discussion}

The analysis shows that the level of waste disposal in the countries of the European Union is most influenced by investments in R\&D. The rest of the indicators did not show a significant impact on waste disposal, the degree of circular material use and trade in recycled materials within the EU and beyond. The Waste Disposal Indicator shows how end-user waste is used as a resource in a circular economy. Although it accounts for about $10 \%$ of all waste generated in the EU, due to its heterogeneous composition, the sustainable management of municipal waste is a challenge. The recycling rate of municipal waste is a good indicator of the quality of the entire waste management system. The indicator of investment in $R \& D$ indicates that waste disposal requires the development of new technologies and infrastructure, training of qualified personnel in this area.

As for Russia, the clear understanding of the cyclic economy principles plastics manufacturers and processors are not formed. It is necessary to form a systematic approach to the waste disposal process. The availability of waste processing equipment, but the lack of an established system of separate waste collection, strongly hinders the connection to the global waste reduction process. Recently, there have been positive trends in this process. The national project "Ecology" covers a program for the disposal of solid household waste, which will be financed jointly with Russian businesses. Within the framework of this program, about 30 million tons of waste will be processed in the country annually, and another 20 million tons will be utilized [23]. The enterprises of the polymer industry set the task of including in the process of waste-free production and the transition to a circular economy. Since the beginning of 2019, a new system for waste management has been operating in Russia: there are still some difficulties, but many market participants are confident that there will be further development of the recycling segment. [24] According to forecasts of the Ministry of Natural Resources of the Russian Federation, by 2024 the level of waste sorting may reach $60 \%$, and the level of utilization - 36\% [25-28]. 


\section{Conclusion}

Observing the trends in waste disposal in European countries, we can talk about a decrease in the volume of annually generated household waste. Regression dependences of the efficiency indicators of the waste disposal policy on the level of GDP, R\&D costs, human resources in science and technology are modelled. Regression analysis showed:

a) the recycling rate of waste is significantly influenced by investments in R\&D. Indicators of the GDP and the number of people employed in R\&D, did not have a significant importance. Financial investments in R\&D will allow the development of new technologies in the field of waste disposal and the return of recycled material to the circular economy;

b) the circular material use rate none of these factors has no effect;

c) trade in secondary raw materials also does not depend on the level of GDP, R\&D costs, human resources in science and technology.

Thus, the efficiency of waste management policy depends primarily on investments in R\&D.

Analysis of waste management in the EU countries revealed the following patterns:

- countries have economic and legal instruments that secure responsibility;

- separate collection of household waste is developed (as a rule, there is a mandatory system of separate collection of waste in four fractions: glass, paper, metal and plastic). It should also be noted the high degree of public awareness;

- waste composting (domestic, industrial) is actively developing;

- great attention is paid to waste recycling ("recycling economics").

When it comes to waste recycling, Russia needs to follow a common European route. It is important to use and apply the experience of European countries in combating waste disposal, otherwise the consequences can lead to environmental problems.

\section{References}

1. Preventing plastic waste in Europe EEA [Electronic resource], 2 (2019) Available at: https://www.eea.europa.eu/publications/preventin g-plastic-waste-in-europe

2. The case for increasing recycling: Estimating the potential for recycling in Europe Briefing (Country) Briefing (all) [Electronic resource] (18 June 2020) Available at: https://www.eea.europa.eu/themes/waste/wastemanagement/the-case-for-increasing-recycling

4. The case for increasing recycling: Estimating the potential for recycling in Europe Briefing 03/20 [Electronic resource] Available at: https://www.eea.europa.eu/publications/the-casefor-increasing-recycling

5. P. Ghisellini, C. Cialani, S. Ulgiati, A review on circular economy: The expected transition to a balanced interplay of environmental and economic systems, Journal of cleaner production, 114 (7), 11-32 (2016)

6. L.A. Mochalova, D.A. Grinenko, V.V. Yurak, Solid municipal waste management system: foreign and domestic experience, Bulletin of the Ural State Mining University, 3 (47), 97-101 (in Russian) (2017) DOI: 10.21440/2307-2091-20173-97-101

7. V.A. Rybak, A. Shokr, A.D. Grib, Scientific and methodological foundations and software for automating the assessment and analysis of the parameters of promising ecologically safe technologies (Minsk: Republican Institute of Higher Education, 2017, 263)

8. D.A. Krivul'kin, L.B. Efremova, International experience in the disposal of solid waste and the possibility of its use in Russia, International Journal of Applied Sciences and Technologies «Integral», 3 (61), 8 (in Russian) (2018)

9. T. Narancic, K.E. O'connor, Plastik waste as a global challenge: are biodegradable plastics the answer to the plastic waste problem?, Microbiology, 165 (2), 129-137 (2019)

10. A.D. Cuéllar, M.E. Webber, Wasted food, wasted energy: the embedded energy in food waste in the United States, Environmental Science and Technology, 44 (16), 6464-6469 (2010)

11. Global Waste Management Outlook, United Nations Environment Programme, International Waste Management Association [Electronic resource] (2015) ISBN: 978-92-807-3479-9. Available at: https://wedocs.unep.org/handle/20.500.11822/967 2

12. Yi. Nikulichev, Waste management, The experience of the European Union 55 (2017)

13. Directive $2008 / 98 / \mathrm{EC}$ of the European Parliament, 3, 17

14. K. Paritosh, V.Yadav, V. Vivekanand, S.K. Kushwaha, A. Chawade, N. Pareek, Food waste to energy: an overview of sustainabke approaches for food waste management and nutrient recycling, BioMed Research International, 2017, 237 (2017)

15. J. Kaazke, B.M. Wilke, N. Sliusar, G. Ilinykh, O. Ulanova, A. Tulokhonova, Testing of different waste analysis tools for municipal solid waste, Proceedings of Institution of Civil Engineers: Waste and Resource Management, 171 (1), 21-30 (2018)

16. F. Cucchiella, I. D'Adamo, M. Gastaldi, Sustainable waste management: waste to energy plant as an alternative to landfill, Energy Conversion and Management, 131, 18-31 (2017)

17. E. Antonetti, G. Iaquaniello, A. Salladini, L. Spadaccini, S. Perathoner, G. Centi Waste to chemicals for a circular economy: the case of UREA production (waste to UREA), ChemSusChem, 10 (5), 912-920 (2017) 
18. S. Sharma, S. Basu, N.P. Shetti, T.M. Aminabhavi, Waste to energy nexus for circular economy and environmental protection: recent trends in hydrogen energy, The Science of the Total Environment, 713, 136 (2020)

19. L. Pshebelskaya, A. Lednitskiy, Municipal waste management: trends and prospective direction, Wofkof BSTU, 5 (2), 111-115 (2020)

20. Plastics - the Facts, An analysis of European plastics production, demand and waste data, Brussels, Belgium (2018)

21. K 2019: Plastics Europe unveils updated plastics data and Voluntary Commitment progress Plastics Europe AISBL Press Release Düsseldorf, 17-10-2019 (2019)

22. Plastics - the Facts, An analysis of European plastics production, demand and waste data, Brussels, Belgium (2019)

23. Recycling rate of municipal waste [Electronic resource], Eurostat Available at: https://ec.europa.eu/eurostat/databrowser/view/cei _pc031/default/table?lang=en

24. Plastics 2030 PlasticsEurope's Voluntary Commitment to increasing circularity and resource efficiency, Brussels, Belgium (2019)

25. Interplastica, Sibur mag., 14 (2019)

26. INVENTRA: polymer recycling in Russia Plastinfo mag, 13-03-2019 (2019) [Electronic resource] Available at: https://plastinfo.ru/information/articles/682/

27. A. Starodubova, D. Sultanova, A. Karimov, The concept of balanced development of waste management [Electronic resource], E3S Web of Conferences: ICEPP 2020, 161 (2020)

28. A. Khaertdinova, D. Sultanova, D. Iskhakova, A. Karimov, Recycling of Polymers - An Opportunity or a Threat to the Economy?, E3S Web of Conferences: ICEPP 2020, 161 (2020)

29. D. Sultanova, A. Maliashova, L. Abzalilova, R. Sultanova, The main obstacles for development of international activity with russian-european chemical clusters: environ-mental aspect, E3S Web of Conferences: ICEPP 2020, 161 (2020). 